\title{
Selection and Evaluation of Reference Genes for ddPCR-Based Transcript Abundance Studies in Oidiodendron Maius Across Varying Carbon Sources
}

Erin Feldman ( $\square$ erin.feldman.82@gmail.com )

University of British Columbia Okanagan Campus

Elena Martino

University of Turin

Annegret Kohler

University of Lorraine

Daniel Durall

University of British Columbia Okanagan Campus

Melanie Jones

University of British Columbia Okanagan Campus

\section{Research Article}

Keywords: Reference genes, Oidiodendron maius, ericoid mycorrhiza, ddPCR, gene expression, ascomycete, normalization

Posted Date: January 4th, 2021

DOI: https://doi.org/10.21203/rs.3.rs-131970/v1

License: (c) (i) This work is licensed under a Creative Commons Attribution 4.0 International License.

Read Full License 


\section{Abstract}

Background When identifying transcript abundance in response to treatment, accurate quantification is critical, especially when examining subtle differences in expression. In particular, data normalization is necessary to account for differences among samples including those associated with RNA quantity and quality. Due to the capacity of droplet digital PCR to absolutely quantify the copy number of the target gene in a given sample, normalization, such as the use of an internal control gene, has not customarily been considered obligatory. Decades of quantitative PCR research have shown, however, that the use of endogenous controls undoubtedly aid in correcting sample variability. With our limited knowledge of gene function in many fungi, typical 'housekeeping genes' commonly used as internal references may not be relevant in these organisms. This study aimed to identify and validate suitable reference genes for transcript abundance studies in Oidiodendron maius, a globally distributed, model ericoid mycorrhizal fungus.

Results A shortlist of 251 non-differentially expressed genes was generated from RNA-Seq analyses of $O$. maius grown on three different carbon sources or in symbiosis with Vaccinium myrtillus. Subsequently, a set of criteria (stable expression, valid annotation and relatively high expression) was applied to select three candidate reference genes. These three genes were validated across a further eleven carbon sources using ddPCR and the application of geNorm and NormFinder stability analysis algorithms. Expression stability analysis of three genes - EfTu, vma, and sar-confirmed their reliability as internal references; the geometric mean of their expression values demonstrated the highest stability as a normalization factor.

Conclusions We propose the use of the geometric mean of $O$. maius genes EfTu, vma and saras a reference tool to normalize RNA expression in ddPCR assays. These newly selected and validated reference genes will increase reliability and reproducibility when studying transcriptional responses of $O$. maius at different developmental stages and/or under a range of physiological conditions. In addition, the list of 251 non-differentially expressed genes can serve as a valuable resource for selecting reference genes for related experiments and enhances the limited information available on 0 . maius.

\section{Background}

The Fungi comprise a monophyletic kingdom, recently estimated at approximately 5 million species worldwide, with about 100,000 currently described (1). They are essential decomposers in the nutrient cycles of many ecosystems and, as root symbionts, they are critical to the growth of nearly $90 \%$ of plant species. Despite their significance, we are still in the early stages of understanding gene function in most fungal groups. Improving knowledge of gene function often begins with investigation of the expression of genes of interest under a broad range of treatment conditions. The most commonly used and wellestablished analytical method to examine transcript abundance has been real-time, or quantitative, polymerase chain reaction (RT- or q-PCR), but the recent advent of droplet digital PCR (ddPCR) allows for accurate quantification of samples varying in quality and starting concentration with no requirement for standard curves or exogenous controls (2). 
In the ddPCR method, samples are diluted and divided into multiple 'partitions' ( 20,000 nanoliter-sized emulsified water-in-oil droplets in the case of the BioRad QX200 ${ }^{\mathrm{TM}} \mathrm{ddPCR}^{\mathrm{TM}}$ system (Bio-Rad Laboratories, Hercules, CA, USA)) and subjected to endpoint PCR. This partitioning has the effect of diluting the target DNA, such that some droplets contain zero copies of the target (negative), while others contain one or more copies (positive). The absolute quantity of DNA can then be calculated from the number of positive and negative droplets using Poisson statistics $(3 ; 4)$. This partitioning into a large number of discrete tests increases sensitivity and dynamic range (5). Droplet digital PCR technology offers several advantages over conventional qPCR including lower sensitivity to inhibitors, lack of susceptibility to variations in PCR and reverse transcriptase (RT) efficiency, absolute quantification of the target without requiring a standard curve, and increased precision in detection of small-fold changes in gene expression $(<1.25$, which is the limit of qPCR) (2).

Currently, the primary use of $\mathrm{ddPCR}$ is detecting copy number variations and rare mutations in gDNA sequences (e.g. (6)). Increasingly, however, it is becoming an indispensable tool in transcript abundance analysis as it exhibits greater sensitivity than QPCR when examining subtle fold-differences and has benefits when mRNA is in low abundance (7). Additionally, ddPCR allows for reliable and reproducible measurements when anticipating closely related gene sequences or in the examination of highly similar mRNAs, such as those in multigene families (8). Due to the capacity of ddPCR to absolutely quantify the number of copies of the target in a given sample, normalization, such as the use of a reference gene, is not considered obligatory. The assumed absolute quantification, however, relies on invariable sample input, which can be affected by the source of tissue as well as the efficiency of the RT step (9).

Recent research suggests that the application of a normalization method may be beneficial for ddPCR data, especially in instances of low replication or highly variable sample quality (10), thus providing a more accurate representation of gene expression changes. Normalization aids in correcting the variability that arises from differences in initial sample amount, variable growth conditions, recovery and quality differences during RNA extraction, cDNA synthesis efficiency, and differences in the overall transcriptional activity of the tissue in response to treatment. It is often difficult to normalize mRNA samples, so internal control genes (reference genes) have frequently been used as a normalization factor in qPCR experiments, resulting in a relative quantification of the gene of interest.

These internal control genes have traditionally been 'housekeeping genes' (constitutively expressed genes involved in normal cellular function); however, many studies use these genes as normalization factors without proper validation, disregarding the fact that QPCR results for transcript abundance studies are highly dependent on the reference genes chosen (11). It is critical that reference genes maintain stable expression between tissues, cells or treatment groups.

Reference genes typically used for quantification of transcripts include elongation factors (e.g. (12)), actin (e.g. (13)), tubulin, glyceraldehyde- 3-phosphate-dehydrogenase or ribosomal RNA (18S or 28S) (14). While these genes are constitutively expressed in nearly all organisms, variation in transcript abundance due to regulation can be seen between species and even within species across experimental 
conditions $(15 ; 16)$. Suzuki et al. (17) reviewed qPCR gene expression studies from high-impact journals and found that glyceraldehyde 3-phosphate dehydrogenase, beta-actin, 18S and 28S rRNA were used as single control genes for normalization in more than $90 \%$ of the studies reviewed. Unfortunately, the use of an inappropriate reference gene, i.e., one with variable expression, can lead to inaccurate calculations of the expression level of target genes and, therefore, incorrect interpretations regarding the function of those target genes (11). Furthermore, because no single gene maintains constant expression in all examined tissues and cells under all experimental conditions (18), multiple reference genes may be required for an experimental system. More recently, many studies examining the validity of reference genes for qPCR have been carried out in plant $(10 ; 19)$, and animal models (20), including humans (21), but very few have examined fungi. Among those studies focused on fungi, the gene expression quantification method used has been exclusively qPCR and the results are variable. The general consensus is that at least two reference genes should be used for accurate normalization; however, the specific genes used for normalization are dependent on organism and experimental conditions.

Cusick et al. (22) used combined stability values from NormFinder and Best Keeper software to show that vma genes (V-type proton ATPase catalytic subunits) were the most stable transcripts for qPCR studies in the model fungus Neurospora crassa under varying environmental conditions and that actin was the least stable of 12 genes examined. In an examination of eleven potential reference genes, Song et al. (23) found that ubiquitin-conjugating enzyme (UBC) and elongation factor 2 (EFTu) were the most stable reference genes for qPCR studies in Puccinia helianthin; they also concluded that actin and tubulin were expressed in extremely low levels in certain tissue types and were not appropriate reference genes. Lyu et al. (24) had similar findings in their selection of reference genes for qPCR in Trichoderma afroharzianum using five different stability analyses; EF1 was found to be the most stably expressed reference gene, whereas alpha tubulin and actin showed the least stable expression. Llanos et al. (25) analyzed 12 functionally unrelated candidate reference genes for Talaromyces versatilis by RT-qPCR assays over more than 30 relevant culture conditions using geNorm and found that six of these ( $u b c B, s a c 7$, fis 1 , sarA, TFC1 and UBC6) were stable across all conditions. They suggest geometric averaging of at least three of these genes (or their homologues) and propose their use in all filamentous fungi (25). Using the NormFinder and geNorm software, Steiger et al. (26) evaluated six potential reference genes in 34 samples from diverse conditions for Trichoderma reesei and found that sar1, which encodes a small GTPase, was the most stable gene, whereas act (encoding actin) was not amongst the best validated ones; they suggest that sar1 and at least one other reference gene be used to normalize transcript analysis. To our knowledge, studies examining appropriate reference genes for normalization in transcript abundance studies utilizing ddPCR in fungi have not been conducted.

Oidiodendron maius ((G. L. Barron 1962), Leotiomycetes, Ascomycota) (27) is a multi-trophic fungus, growing both as a saprotroph and as a symbiont (28). It has been isolated from sphagnum peat bogs (27), decaying wood (29), and roots of spruce (30;31), salal (32) and oak (33). Several Oidiodendron spp., including 0 . griseum have been proposed as ericoid mycorrhizal fungi due to their ability to form typical intracellular coils in the roots of the monophyletic plant family Ericaceae (34-36). However, more recent analysis of rDNA ITS sequences suggests that many Oidiodendron isolates may have been misidentified 
in older studies, and that only 0 . maius demonstrates mycorrhizal associations with Ericaceae in the field $(37 ; 38)$. Although few experiments have been done to determine benefits from the association $(39 ; 40)$, there are no reported negative effects of $O$. maius on plant partners. Like other Oidiodendron spp., $O$. maius exhibits classic characteristics of saprotrophy (28): it sporulates prolifically, grows relatively quickly in culture on a variety of media, produces a broad complement of degradative enzymes $(40 ; 41)$, and is effective at eroding complex organic residues, such as the cell walls of Sphagnum (42). Much of the work on $O$. maius has focused on its metal tolerance $(43)$, but with its published genome $(40 ; 44)$ and transcriptomes $(40 ; 45)$, it has become a model organism for the investigation of the genetic and functional basis of the ericoid mycorrhizal symbiosis.

Several groups have used individual reference genes to normalize qPCR data from 0 . maius, including elongation factor $1(46 ; 47)$ and beta-tubulin $(48)$; these genes were assumed to be stably expressed "housekeeping genes", but this was not confirmed experimentally. DiVietro et al. (49) used the Normfinder algorithm to assess the stability of beta-tubulin, elongation factor 1a and triose phosphate isomerase for use as reference genes in qPCR of $O$. maius; the most stable expression profile was derived from the average between $b$-tubulin and elongation factor $1 a$ expression values. Attempts to validate reference genes for ddPCR of $O$. maius have not been made. Theoretically, genes that are stable across treatments would be potential reference genes for either classical QPCR or ddPCR, but the need to confirm stability remains.

When selecting appropriate reference genes, several characteristics are important to consider. Relatively stable expression across various treatments ensures that the expression does not vary due to nutrient source or physiological condition; a relatively high expression level ensures that changes in expression will be detectable; and annotation provides some context for why the expression of these genes remains stable. Screening transcriptome datasets has been demonstrated as a quick and efficient means of selecting candidate reference genes that meet these criteria for a particular species $(50 ; 51)$. In the work reported here, our objective was to select and validate appropriate reference genes for transcript abundance studies by ddPCR in $O$. maius. Using in-silico analysis to mine RNA-seq data from 0 . maius cultivated on varying carbon sources as well as during symbiosis (44), a list of 251 annotated genes with invariant expression was generated as a resource for selecting reference genes. Three of these genes, EfTu (protein ID 102574), vma (protein ID 31957), and sar (protein ID 18772), were further investigated by ddPCR analysis and are proposed as reference genes for studying transcriptional response across different developmental stages and physiological conditions in 0 . maius. Additionally, we show that the geometric mean of these three genes increases their reliability as a means of normalizing variable transcript abundance data.

\section{Results And Discussion}

\section{Transcriptome sequencing to identify genes with stable expression across three carbon sources and in symbiosis}


Analysis of three RNA-Seq datasets from $O$. maius free living mycelium (FLM) grown on modified MMN supplemented with glucose, BSA and peat (E. Feldman, unpublished) and two RNA-Seq data sets from $O$. maius grown on modified MMN supplemented with BSA alone (FLM) or in symbiosis (MYC) with Vaccinium myrtillus (44) revealed a list of 251 putative reference genes that met several criteria: (1) stable expression across the five treatments (based on ratio of RPKM Means); (2) valid annotation; and (3) relatively high expression level (RPKM means > 15). The resultant shortlist of 251 candidate reference genes will provide an excellent resource for researchers looking to examine transcript abundance in 0 . maius in the future (Fig. 1, Supplemental Table S1).

Approximately one third of the shortlisted genes were involved in cellular processes and signalling, including chaperone proteins, ubiquitins and related proteins, ADP-ribosylation factors and three tubulin genes. Approximately one quarter of the shortlisted genes were transcription factors, transcriptional regulatory proteins, elongation factors and other genes related to information storage and processing. Another twenty percent of the shortlisted genes encoded proteins involved in metabolism, primarily those involved in amino acid and coenzyme transport/metabolism as well as several enzymes involved in secondary metabolite synthesis. The remainder were poorly characterized with only a general function predicted. Other than the aforementioned tubulin genes, this shortlist did not contain any of the transcripts typically considered housekeeping genes, nor those previously suggested for use as reference genes in qPCR of 0 . maius (46-49). This absence of typical housekeeping genes supports the need to validate reference genes in the context of each experimental system.

Three of the shortlisted candidate reference genes were selected for further study, based on homology to reference genes previously used in quantitative expression studies in fungi (22-25). The genes chosen for this study (Table 1) were selected based on InterPro Descriptions; these homology-based annotations indicate that transcript 102649 codes for a translation elongation factor 2 (EFTu) with GTPase activity, potentially involved in translation, ribosomal structure and biogenesis; transcript 18772 codes for a small GTPase (ARF/SAR) subunit SAR1/ GTP-binding ADP-ribosylation factor Arf1, involved in GTP binding and intracellular protein transport; and transcript 32032 codes for a proton-transporting two-sector ATPase complex (ATPase_F1/V1/A1) with hydrogen ion transmembrane transporter activity. For the purpose of this work, I have named the genes according to their proposed function. The genes are categorized in three distinct gene ontology terms and their products are likely associated with three different cellular components/compartments: ribosome, cytosol, and membrane. There is no evidence of functional relation to one another; therefore, it was assumed that independent confirmation of expression stability of each gene between treatments would support this reference gene selection process. 
Table 1

Selected candidate reference genes with stable expression across various culture conditions in Oidiodendron maius*

\begin{tabular}{|c|c|c|c|c|c|c|}
\hline \multirow[b]{2}{*}{ Name } & \multirow[b]{2}{*}{ Transcript ID } & \multirow[b]{2}{*}{$\begin{array}{l}\text { Protein } \\
\text { ID }\end{array}$} & \multicolumn{4}{|c|}{ RPKM Ratio } \\
\hline & & & Putative function & $\begin{array}{l}\text { FLM/Peat } \\
\text { vs } \\
\text { FLM/ } \mathrm{NH}_{4}\end{array}$ & $\begin{array}{l}\text { FLM/Peat } \\
\text { vs } \\
\text { FLM/BSA }\end{array}$ & $\begin{array}{l}\text { FLM/NH } \\
\text { vs } \\
\text { FLM/BSA }\end{array}$ \\
\hline EfTu & jgi|Oidma1|102649| & 102574 & $\begin{array}{l}\text { Translation } \\
\text { elongation factor } \\
\text { EFTu/EF1A }\end{array}$ & 1.119 & 1.055 & 0.943 \\
\hline sar & jgi|Oidma1|18847| & 18772 & $\begin{array}{l}\text { GTP-binding } \\
\text { protein SAR1; } \\
\text { ARF/SAR } \\
\text { superfamily }\end{array}$ & 1.058 & 1.059 & 1.001 \\
\hline$v m a$ & jgi|Oidma1|32032| & 31957 & $\begin{array}{l}\text { ATPase, } \\
\text { F1/V1/A1 } \\
\text { complex, } \\
\text { alpha/beta } \\
\text { subunit }\end{array}$ & 0.986 & 0.997 & 1.011 \\
\hline \multicolumn{7}{|c|}{$\begin{array}{l}\text { *Transcript abundance data evaluated in this study was obtained through RNA-SEq. Stable } \\
\text { expression is here defined as a Reads Per Kilobase Million (RPKM) ratio approximating one. O. maius } \\
\text { samples were grown on the following media: } \mathrm{NH}_{4}=\text { Modified Melin Norkrans (MMN); BSA = MMN }\end{array}$} \\
\hline
\end{tabular}

A total of three primer pairs were designed and tested using a touchdown PCR procedure for each transcript selected as a candidate reference gene (Table 2). For all primer pairs except E25, a single amplicon was observed by electrophoretic separation. Primer pairs E22, S12 and V35 produced amplicons which aligned to a single, intended transcript and were subsequently used for ddPCR amplification. 
Table 2

Primer pairs designed for amplification of candidate reference genes in Oidiodendron maius*

\begin{tabular}{|c|c|c|c|c|}
\hline $\begin{array}{l}\text { Gene Name/ } \\
\text { Transcript ID }\end{array}$ & $\begin{array}{l}\text { Primer } \\
\text { Pair } \\
\text { Name }\end{array}$ & $\begin{array}{l}\text { Forward primer Sequence } \\
\left(5^{\prime} \rightarrow 3^{\prime}\right)\end{array}$ & $\begin{array}{l}\text { Reverse Primer Sequence } \\
\left(5^{\prime} \rightarrow 3^{\prime}\right)\end{array}$ & $\begin{array}{l}\text { Expected } \\
\text { Amplicon } \\
\text { Size }\end{array}$ \\
\hline EfTu / & E22 & ACAGGTAGCGACAAAGG & GTATAGCTCGAGGATCACG & 112 \\
\hline \multirow[t]{2}{*}{102649} & E23 & TCTGGGTGCCATTTACG & ССААТСССТТССТСАТСС & 108 \\
\hline & E25 & GATGATCTGGAGGATCTGG & TCTGCTTCTCTGCATCC & 130 \\
\hline sar / & S11 & TCTGATGGTTGGGTTGG & GTTGAAGCCGATTGTGG & 97 \\
\hline \multirow[t]{2}{*}{18847} & S12 & TCGTCGACAGTAATGACC & GCAGATCTTGCTTGTTGG & 120 \\
\hline & S15 & CACAATCGGCTTCAACG & CGACGACGAAGATAATGC & 137 \\
\hline vma / & V32 & GATCCTGCTCGACTATCC & GGTTGTTCAGCCTTTCC & 192 \\
\hline \multirow[t]{2}{*}{32032} & V34 & GAGTTTGGTTCCGTTGC & СTCCATCTCTAGGTTGCC & 139 \\
\hline & V35 & CTGGCAACCTAGAGATGG & GTGATCCAGAATCCAGAGG & 165 \\
\hline
\end{tabular}

Optimization of EvaGreen ddPCR assays

The optimum temperature for annealing/extension during ddPCR was determined for each primer pair using a temperature gradient. This optimization determined the annealing/extension temperature that demonstrated the greatest balance between high droplet count and cluster separation of positive and negative droplets while reducing 'rain' (droplets with intermediate fluorescence) (52). All gradient assays produced non-specific amplification ('rain') at all temperatures in the gradient, although the EfTu (E22) primer set showed the greatest cluster separation (Fig. 2A). Cluster separation was strongest for all primer pairs at lower temperatures (Fig. 2); consequently, $54{ }^{\circ} \mathrm{C}$ was selected as the annealing/ extension temperature for all experimental assays.

\section{Stability of candidate ddPCR reference genes evaluated for Oidiodendron maius cultured on a variety of carbon sources}

It is critical that reference genes maintain invariable expression across a wide variety of carbon sources. To evaluate whether the selected candidate reference genes could be utilized as internal controls for normalization of ddPCR expression data, their transcript levels were quantified across eleven carbon treatments. The resulting analysis showed variability among and between treatments, as expected, in response to variable amounts of starting material (Fig. 3). While a few studies have examined reference gene stability for use in ddPCR, these analyses have been conducted solely on qPCR data $(10 ; 53)$. The geNorm algorithm was designed for qPCR data and, as such, the input data used is raw expression data. 
While we are unaware of any other application of geNorm to ddPCR data, the algorithm is based on average pairwise variation between the gene of interest and all other genes examined (18), and, therefore, should be applicable to expression values derived from ddPCR. Similarly, the NormFinder algorithm allows input of any linear scale expression quantities, hence any expression data obtained through any quantitative method can be analyzed (54). Furthermore, it is a model-based system that compares interand intra-group variation, so as long as there are at least three candidate genes examined, over at least eight samples (54), the resulting stability values should be relevant to ddPCR quantification. Another algorithm, BestKeeper (55), has often been used to validate reference gene stability; however, data input is in the form of raw crossing points (CP) (56) or threshold cycles (Ct) (57) generated by a real-time PCR platform, which are not compatible with the data obtained through ddPCR experiments. The geNorm algorithm does not allow for zero values, so all samples from this work that contained one or more "No Call" readings were omitted from the stability calculation for both algorithms (i.e. nine assays - one for each candidate reference gene target - were excluded for the carbon sources: peat DOM, field soil and lignin) resulting in 32 samples being used for the calculation (i.e. field soil and lignin carbon sources were only present as two biological replicates in the stability analysis).

NormFinder ranked the most stable reference gene as EfTu, followed by vma, then sar (Fig. 4A). geNorm ranked $v m a$ as the most stable reference gene, followed by EfTu and sar (Fig. 4B), though all three candidate reference genes fell below the $\mathrm{M}$ value stability cut-off of 1.5. The algorithms were also applied to the geometric means (Geomean) of two or all three candidate reference genes (Fig. 4C, D). NormFinder ranked the Geomean of the three candidate genes as the most stable, followed by the Geomean of sar and vma the Geomean of EfTu and sar, and the Geomean of EfTu and vma (Fig. 4C). Interestingly, it ranked the stability of EfTu alone as greater than the latter two Geomeans of two genes. The geNorm algorithm also ranked the Geomean of the three candidate genes as the most stable, followed by the Geomean of EfTu and sar, the Geomean of sar and vma, and the Geomean of EfTu and vma (Fig. 4D). In the case of geNorm, the use of any Geomean was considerably more stable than the use of any single reference gene. As they are not functionally related, it is unlikely that this correlation results from coregulation of the three genes.

Numerous qPCR studies have demonstrated that the use of a single reference gene is inadequate for normalizing quantitative expression and the results presented here support that. It is impractical, however, to quantify multiple reference genes when only a few target genes are being examined, or if RNA is limiting (18); therefore, the geometric mean of three constitutively expressed genes is considered a suitable method to normalize quantitative expression (18). Using multiple reference genes for normalization is reasonable, as it can be assumed that the variation in transcript abundance for any single gene is higher than the variation in the average transcript abundance of multiple genes.

\section{Conclusions}

This work is the first study to show that a data set derived from a massive RNA sequencing effort for several culture conditions can be used for the identification of reference genes in 0 . maius. In this study, a 
list was generated of 251 annotated $O$. maius genes with invariant expression during cultivation on varying carbon sources, as well as during symbiosis. Because $O$. maius is considered a model species for studies of ericoid mycorrhizal fungi, this list will be a valuable resource for selecting reference genes for future gene expression studies. Furthermore, the work reported here enhances the limited information available on this organism. Included in this list, the genes EfTu (transcript 102649), vma (transcript 32032), and sar (transcript 18847) were expressed at stable levels in all samples studied and were examined as candidate reference genes for transcript abundance studies.

Droplet digital PCR is a powerful tool to analyze transcript abundance profiles across multiple treatments and when fold-changes are low; however, like all transcript abundance quantification methods, it requires a stable and reproducible normalization method. Using two different algorithms to determine their stability, EfTu (transcript 102649), vma (transcript 32032), and sar (transcript 18847) were demonstrated to be stable reference genes, though their rank order differed between NormFinder and geNorm. Both algorithms demonstrate, however, that the geometric mean of all three candidate reference genes increased their stability appreciably. Therefore, we propose the geometric mean of these three genes be used as an appropriate normalization factor for future studies of transcriptional response across different developmental stages and physiological conditions in 0 . maius.

\section{Materials \& Methods}

\section{Strain}

The Oidiodendron maius (MUT1381/ATCC MYA-4765) isolate used here had been isolated from roots of Vaccinium myrtillus growing in zinc-contaminated experimental plots in the Niepolomice Forest, Poland according to Pearson and Read $(58 ; 59)$. The isolate is capable of forming typical ericoid mycorrhizae with axenic Calluna vulgaris (60) and Vaccinium myrtillus (40) seedlings. The genome of 0 . maius as well as transcriptomes for both the free-living mycelium and the fungus in symbiosis with Vaccinium myrtillus, have been sequenced (44).

\section{In-silico analysis of RNA-seq data}

Five RNA-seq datasets from 0 . maius $\mathrm{Zn}$ were analyzed in the current study: three unpublished data sets (E. Feldman, unpublished) and two from Kohler et al. (44; the complete data sets have been deposited in NCBI's Gene Expression Omnibus and are accessible through GEO Series accession number GSE63947). In all cases, fungal cultures were grown for 45 days on Modified Melin Norkrans (MMN) plates, overlaid with sterile cellulose membranes (autoclaved in $\mathrm{ddH}_{2} \mathrm{O}$ twice, with 24 hours in between), with a range of amendments (Table 3). The MMN medium contained: $0.075 \mathrm{~g} \mathrm{~L}^{-1}\left(\mathrm{NH}_{4}\right)_{2} \mathrm{HPO}_{4}$ (filter sterilized, $0.2 \mu \mathrm{m}$, added after autoclaving), $1 \mathrm{~g} \mathrm{~L}^{-1}$ glucose, $0.5 \mathrm{~g} \mathrm{~L}^{-1} \mathrm{KH}_{2} \mathrm{PO}_{4}, 0.066 \mathrm{~g} \mathrm{~L}^{-1} \mathrm{CaCl} 2.2 \mathrm{H} 2 \mathrm{O}, 0.025 \mathrm{~g} \mathrm{~L}^{-1} \mathrm{NaCl}$, $0.15 \mathrm{~g} \mathrm{~L}^{-1} \mathrm{MgSO}_{4} \cdot 7 \mathrm{H}_{2} \mathrm{O}, 0.1 \mathrm{~g} \mathrm{~L}^{-1}$ thiamine $\mathrm{HCl}$ (filter sterilized, $0.2 \mu \mathrm{m}$, added after autoclaving), $1 \mathrm{mg}$ $\mathrm{L}^{-1} \mathrm{FeCl}_{3} \cdot 6 \mathrm{H}_{2} \mathrm{O}$ and $10 \mathrm{~g} \mathrm{~L}^{-1}$ agar; $\mathrm{pH}$ was adjusted to 4.7 . 
Table 3

Amendments made to Modified Melin Norkrans media to support growth of Oidiodendron maius.

\begin{tabular}{|c|c|c|c|c|c|c|}
\hline $\begin{array}{l}\text { Treatment } \\
\text { Name }\end{array}$ & Study & $\begin{array}{l}\text { Glucose } \\
\left(1 \mathrm{~g} \mathrm{~L}^{-1}\right)\end{array}$ & $\left(\mathrm{NH}_{4}\right)_{2} \mathrm{HPO}_{4}$ & $\begin{array}{l}\text { BSA } \\
(0.1 \mathrm{~g} \\
\left.\mathrm{L}^{-1}\right)\end{array}$ & $\begin{array}{l}\text { Peat }^{1} \\
(\sim 10 \mathrm{~g} \\
\text { dry } \\
\text { weight })\end{array}$ & Notes \\
\hline $\mathrm{FLM} / \mathrm{NH}_{4}$ & $\begin{array}{l}\text { present } \\
\text { work }\end{array}$ & + & + & - & - & \\
\hline FLM/Peat & $\begin{array}{l}\text { present } \\
\text { work }\end{array}$ & - & - & - & + & \\
\hline MYC/BSA & $\begin{array}{l}\text { Kohler et } \\
\text { al. } 2015\end{array}$ & - & - & + & - & $\begin{array}{l}\text { O. maius colonizing } \\
\text { Vaccinium myrtillus } \\
\text { roots }\end{array}$ \\
\hline
\end{tabular}

Three criteria were applied to these five transcriptomes to generate a short list of potential candidate reference genes: (1) the fold change (based on Reads Per Kilobase Million; RPKM) was equal to approximately one (between 0.8 and 1.2) among all treatments (uniform expression despite treatment difference, as suggested by Manoli et al. (61)), (2) annotation was available (including a valid annotation from InterPro (excluding "protein of unknown function") and a valid Gene Ontology name), and (3) homologous genes had been used previously in other fungi as internal reference genes for qPCR. The online tool Heatmapper (62) was utilized to construct the heatmap from RPKM Means; no clustering method was used.

\section{Cultivation of Oidiodendron maius for use in ddPCR}

Because we planned to assess expression of carbohydrate-active genes in future research, we cultivated O. maius on a greater variety of carbon sources than those previously examined by RNA-SEq. O. maius cultures were maintained on Czapek-glucose agar $\left(3 \mathrm{~g} \mathrm{~L}^{-1} \mathrm{NaNO}_{3} ; 1 \mathrm{~g} \mathrm{~L}^{-1} \mathrm{~K}_{2} \mathrm{HPO}_{4} ; 0.5 \mathrm{~g} \mathrm{~L}^{-1}\right.$ $\mathrm{MgSO}_{4} .7 \mathrm{H}_{2} \mathrm{O} ; 0.01 \mathrm{~g} \mathrm{~L}^{-1} \mathrm{FeSO}_{4} .7 \mathrm{H}_{2} \mathrm{O} ; 0.5 \mathrm{~g} \mathrm{~L}^{-1} \mathrm{KCl} ; 20 \mathrm{~g} \mathrm{~L}^{-1}$ glucose; $10 \mathrm{~g} \mathrm{~L}^{-1}$ agar; $\mathrm{pH}$ adjusted to 6 ) for 45 days in the dark at $25^{\circ} \mathrm{C}$. Fungal plugs from these plates were transferred to glass mesh filters (Whatman Grade GF/F Glass Microfiber Filters, Binder Free, GE Healthcare, 0.6-0.8 $\mu \mathrm{m}$ particle retention) overlaid on MMN $0.1 \%$ glucose plates supplemented with one of eleven additional carbon sources (Table 4) for a further 45 days in the dark at $25^{\circ} \mathrm{C}$ (plates contained $\left(\mathrm{NH}_{4}\right)_{2} \mathrm{HPO}_{4}$ as the sole nitrogen source, unless otherwise stated, to provide a nitrogen source where it may be limiting). The experimental ddPCR assays were performed on cDNA samples from these eleven experimental treatments using at least three biological replicates. 
Table 4

Treatment groups for growth of Oidiodendron maius for use in ddPCR*

\begin{tabular}{|c|c|c|}
\hline Carbon Source & Source C Added $\left(\mathrm{g} \mathrm{L}^{-1}\right)$ & N source $\left(g \mathrm{~L}^{-1}\right)$ \\
\hline glucose $(0.1 \%)$ & & $\left(\mathrm{NH}_{4}\right)_{2} \mathrm{HPO}_{4}(0.075)$ \\
\hline glucose $(0.5 \%$ total $)$ & 0.4 & $\left(\mathrm{NH}_{4}\right)_{2} \mathrm{HPO}_{4}(0.075)$ \\
\hline peat & 0.1 & $\left(\mathrm{NH}_{4}\right)_{2} \mathrm{HPO}_{4}(0.075)+$ peat \\
\hline peat dissolved organic matter (DOM) & $200 \mathrm{~mL} \mathrm{~L}^{-1}$ & $\left(\mathrm{NH}_{4}\right)_{2} \mathrm{HPO}_{4}(0.075)+$ peat DOM \\
\hline field soil & 0.1 & $\left(\mathrm{NH}_{4}\right)_{2} \mathrm{HPO}_{4}(0.075)+$ field soil \\
\hline field soil organic matter (SOM) & $200 \mathrm{~mL} \mathrm{~L}^{-1}$ & $\left(\mathrm{NH}_{4}\right)_{2} \mathrm{HPO}_{4}(0.075)+$ field SOM \\
\hline Bovine Serum Albumin (BSA) & 0.1 & $\left(\mathrm{NH}_{4}\right)_{2} \mathrm{HPO}_{4}(0.075)+\mathrm{BSA}$ \\
\hline cellulose & 0.113 & $\left(\mathrm{NH}_{4}\right)_{2} \mathrm{HPO}_{4}(0.075)$ \\
\hline chitin & 0.113 & $\left(\mathrm{NH}_{4}\right)_{2} \mathrm{HPO}_{4}(0.075)$ \\
\hline pectin & 0.119 & $\left(\mathrm{NH}_{4}\right)_{2} \mathrm{HPO}_{4}(0.075)$ \\
\hline lignin & 0.08 & $\left(\mathrm{NH}_{4}\right)_{2} \mathrm{HPO}_{4}(0.075)$ \\
\hline
\end{tabular}

\section{RNA Extraction and cDNA synthesis}

Fungal tissue was removed from glass mesh filters with a sterile scalpel, placed in pre-weighed RNasefree $1.5 \mathrm{~mL}$ Eppendorf tubes and flash-frozen in liquid nitrogen. Up to $100 \mathrm{mg}$ of flash-frozen fungal tissue was mechanically disrupted by grinding in liquid nitrogen in a sterile mortar and pestle and placed in RNase-free $1.5 \mathrm{~mL}$ Eppendorf tubes on ice. To each tube, $700 \mu \mathrm{L}$ extraction buffer $(100 \mathrm{mM}$ Tris-HCl pH $8,100 \mathrm{mM} \mathrm{NaCl}, 20 \mathrm{mM}$ Na-EDTA, 0.1\% PVP, 1\% sodium-lauryl sarcosine, prepared in diethylpyrocarbonate (DEPC) water) and $700 \mu \mathrm{L}$ acid phenol were added prior to gently inverting the tubes. Tubes were centrifuged for 5 minutes at $14000 \mathrm{rpm}\left(4{ }^{\circ} \mathrm{C}\right)$; all subsequent centrifugation was also performed at $14000 \mathrm{rpm}\left(4^{\circ} \mathrm{C}\right)$. The uppermost phase of the supernatants was transferred to new Eppendorf tubes on ice, to which an equal volume of acid phenol-chloroform-isoamyl alcohol (25:24:1) was added. Tubes were gently inverted several times, then centrifuged for 5 minutes. Supernatants were transferred to new tubes containing an equal volume of chloroform, tubes were gently inverted several times and then centrifuged for 5 minutes. This chloroform extraction and centrifugation was repeated once. Total nucleic acids were precipitated by addition of an equal volume of isopropyl alcohol to the supernatant and gentle inversion. Tubes were incubated for 30 minutes at $-80^{\circ} \mathrm{C}$, then centrifuged 30 minutes. Supernatant was discarded and the pellet was resuspended in $500 \mu \mathrm{L}$ DEPC water. To each tube 
$500 \mu \mathrm{L} 6 \mathrm{M} \mathrm{LiCl}$ was added, then the tubes were gently inverted and kept overnight in ice at $4{ }^{\circ} \mathrm{C}$. Tubes were centrifuged 30 minutes, then the supernatant was discarded and the remaining pellet was washed with $150 \mu \mathrm{L} 70 \%$ ethanol (prepared with DEPC water). The tubes were centrifuged for an additional 5 minutes, the supernatant discarded and the pellet was dried on ice in the fume hood. Once completely dry, the pellet was resuspended in $25 \mu \mathrm{L}$ DEPC water, then the concentration and quality were determined using a NanoDrop ND-1000 UV-visible light spectrophotometer (NanoDrop, Wilmington, DE, USA). Only RNA samples with 260/280 nm wavelength ratio of approximately 2 and 260/230 nm wavelength ratio of approximately 2 were retained. RNA solutions were treated with PerfeCTa ${ }^{\circledR}$ DNase I according to manufacturer's instructions (Quanta Biosciences ${ }^{\text {TM }}$, Beverly, MA, USA). DNase-treated RNA was converted to cDNA using the BioRad iScript RT Supermix for RT-qPCR according to manufacturer's protocol (Bio-Rad Laboratories, Inc., Hercules, California, USA) and stored at $-20^{\circ} \mathrm{C}$.

\section{Primer Design and Validation by Conventional PCR Detection}

Primers were designed for the three candidate reference genes using the IDT PrimerQuest tool which incorporates Primer3 software (version 2.2.3; Integrated DNA technologies, Skokie, Illinois) using the qPCR Intercalating Dyes parameters. Additional parameters included a product size of 75-200 bp (optimum $=125 \mathrm{bp}$ ), melting temperature of $50-65^{\circ} \mathrm{C}$ (optimum $=59^{\circ} \mathrm{C}$ ), GC content of $50-60 \%$ (optimum $=55 \%$ ), GC clamps on both ends ( $3^{\prime} \mathrm{GC}$ clamp $=2 \mathrm{nt}$ ), $50 \mathrm{mM}$ salt concentration, $300 \mathrm{nM}$ oligonucleotide concentration and minimum overlap of $4 \mathrm{nt}$ at either end. Three primer pairs were chosen for each transcript based on forward and reverse primers having similar GC content and melting temperature, where the target sequence had a single hit when BLASTed against the 0 . maius model filtered transcript dataset (40).

CDNA from the MMN + Peat treatment was used for all primer validation by conventional PCR. PCR reaction conditions were $1 \times$ GoTaq buffer, $200 \mu \mathrm{M}$ dNTPs, 1 U GoTaq, $0.1 \mu \mathrm{M}$ F primer, $0.1 \mu \mathrm{M}$ R primer, $100 \mathrm{ng}$ cDNA, 5\% DMSO. Touchdown PCR was run: $3 \mathrm{~min}$. @ $94{ }^{\circ} \mathrm{C}+10\left(1 \mathrm{~min}\right.$. @ $94^{\circ} \mathrm{C}+1 \mathrm{~min}$. $65 \Delta-$ $1{ }^{\circ} \mathrm{C}+1 \mathrm{~min}$. @ $\left.72{ }^{\circ} \mathrm{C}\right)+30\left(1 \mathrm{~min}\right.$. @ $94{ }^{\circ} \mathrm{C}+1 \mathrm{~min}$ @ $60^{\circ} \mathrm{C}+1 \mathrm{~min}$ @ $\left.72{ }^{\circ} \mathrm{C}\right)+9 \mathrm{~min}$. $72{ }^{\circ} \mathrm{C}+\infty @ 4{ }^{\circ} \mathrm{C}$.

\section{All PCR products were run for 60 minutes at $90 \mathrm{~V}$ on a $1 \%$ agarose gel containing Invitrogen ${ }^{\mathrm{m}}$}

SYBR ${ }^{\text {TM }}$ Safe. Gels were photographed under UV light and bands containing the correctly sized amplicons were excised. These excised gel fragments were cleaned using the QIAGEN QIAquick Gel Extraction kit as per manufacturer's instructions. The resulting extractions were sequenced on an Applied Biosystems 3130xI DNA sequencer in the Fragment Analysis and DNA Sequencing Services lab at the University of British Columbia Okanagan campus. Sequenced amplicons were reBLASTed against the $O$. maius model filtered transcript dataset (40) to ensure a single hit with the intended target.

\section{ddPCR Assay with EvaGreen}

Validated primers were used in a ddPCR Assay using a QX200 ${ }^{\text {TM }}$ ddPCR ${ }^{\text {TM }}$ system (Bio-Rad Laboratories, Hercules, CA, USA) according to the manufacturer's standard EvaGreen ${ }^{\circledR}$ protocol. Briefly, each reaction 
contained $2 \mu \mathrm{L}$ of cDNA, $100 \mathrm{nM}$ of each forward and reverse primer, $1 \mathrm{X}$ ddPCR EvaGreen Supermix, $5 \%$ DMSO and molecular-grade water to $20 \mu$ l. Reactions were loaded into the sample wells of a DG8 droplet generation cartridge (Bio-Rad). Seventy $\mu$ l of Droplet Generation Oil for EvaGreen (Bio-Rad) were loaded into the oil wells, and the cartridge was placed in the QX200Droplet Generator (Bio-Rad). The resulting droplets were transferred to a 96-well Bio-Rad PCR plate. The PCR plate was then heat-sealed with a foil seal and placed in the thermocycler. Reaction conditions consisted of initial enzyme activation period at $95^{\circ} \mathrm{C}$ for $5 \mathrm{~min}$; followed by 40 cycles of denaturing at $95^{\circ} \mathrm{C}$ for $30 \mathrm{~s}$ and annealing/extension for $1 \mathrm{~min}$; then dye stabilization at $4{ }^{\circ} \mathrm{C}$ for $5 \mathrm{~min}$ and $90^{\circ} \mathrm{C}$ for $5 \mathrm{~min}$; the ramp rate was $2.5^{\circ} \mathrm{C} / \mathrm{sec}$. Optimal annealing temperature was determined by running a temperature gradient for each primer pair ranging from $54^{\circ} \mathrm{C}$ to $60^{\circ} \mathrm{C}$.

After the amplification, plates were loaded into the Bio-Rad QX200 DropletReader for enumeration of the number of positive and negative droplets based on fluorescence. The number of template molecules per microliter of starting material was estimated by the QuantaSoft ${ }^{\circledR} A P$ software (version 1.6.6.0320, BioRad) using an internal Poisson algorithm to analyze clusters; only droplets above a minimum amplitude threshold were counted as positive. For each primer pair, the PCR reaction mixture without matrix was used as negative control (no template control, NTC). Three biological replicates were run for each carbon source, unless otherwise specified.

\section{ddPCR Stability Analysis}

The stability of the putative reference genes was assessed using the geNormv3 (18) and the NormFinder (54) add-ins for Microsoft Excel. The geNorm add-in allows the calculation, for each reference gene, of the gene expression stability value $M$, which is the average pairwise variation of a particular gene with all other genes. The most stable genes present the lowest $M$ values; genes with $M$ value $\leq 1.5$ are considered highly stable across analyzed samples. Normfinder uses a model-based approach that provides an estimate of both intra- and intergroup expression variation, and calculates a gene stability value; the smaller the stability value, the more appropriate the use as a reference gene.

\section{List Of Abbreviations}

Bovine Serum Albumin (BSA)

Diethylpyrocarbonate (DEPC)

Dissolved organic matter (DOM)

Droplet digital polymerase chain reaction (ddPCR)

Free Living Mycelium (FLM)

Modified Melin Norkrans media (MMN) 
Mycorrhizal (MYC)

Polymerase chain reaction (PCR)

Quantitative polymerase chain reaction (qPCR)

Reads Per Kilobase Million (RPKM)

Reverse transcription (RT)

Soil organic matter (SOM)

\section{Declarations}

Ethics approval and consent to participate: Not Applicable

Consent for publication: Not Applicable

\section{Availability of data and materials:}

The datasets generated during and/or analysed during the current study are currently being deposited in NCBI's GEObank and will have a unique identifier and hyperlink available at the time of publication.

Competing interests: The authors declare that they have no competing interests.

Funding: The experimental research and data analysis by ECF was supported by Natural Sciences and Engineering Research Council of Canada Discovery Grant Program grants RGPIN 170627-2013 to MDJ and RGPIN 05340-2016 to DMD. The contributions of AK were supported by the Laboratory of Excellence ARBRE (ANR-11-LABX-0002-01), the Region Lorraine and the European Regional Development Fund. The contributions of EM were supported by the Laboratory of Excellence ARBRE (ANR-11-LABX-0002-01) and by local funding from the University of Turin. ECF received graduate student travel and research dissemination funding from the University of British Columbia's Okanagan campus.

\section{Authors' contributions:}

Conceived and designed the experiments: all

Performed the experiments: ECF

Analyzed the data: ECF, AK

Contributed reagents/materials/analysis tools: AK, EM, DMD, MDJ,

Wrote the paper: ECF

Edited the paper: MDJ, DMD, AK, EM 
All authors read and approved the final manuscript.

Acknowledgements: We are grateful to Mike Deyholos for multiple useful discussions, to Miranda Hart for providing access to the ddPCR technology, and to Eric Vukicevich for providing training on its use. Ayelign Adal provided helpful comments on an earlier version of this manuscript.

\section{References}

1. Blackwell M. The Fungi: 1, 2, 3 ... million species? Botany. 2011 Mar;98(3):426-438.

2. Baker M. Digital PCR hits its stride. Nat Methods. 2012 May;9:541-544.

3. Hindson BN. High-throughput droplet digital PCR system for absolute quantitation of DNA copy number. Anal Chem. 2011 Nov;83(22):8604-8610.

4. Pinheiro LC. Evaluation of a droplet digital polymerase chain reaction format for DNA copy number quantification. Anal Chem. 2012 Jan;84(2):1003-1011.

5. McCord P. Using droplet digital PCR (ddPCR) to detect copy number variation in sugarcane, a highlevel polyploid. Euphytica. 2016 Feb;209:439-448.

6. Zhao Z, Liu H, Wang C, Xu J. Comparative analysis of fungal genomes reveals different plant cell wall degrading capacity in fungi. BMC Genomics. 2013 Apr;14:274.

7. Whale AS, Huggett JF, Cowen S, Speirs V, Shaw J, Ellison S, et al. Comparison of microfluidic digital PCR and conventional quantitative PCR for measuring copy number variation. Nucleic Acids Res. 2012 Jun;40(11):e82.

8. Vasina DV, Moiseenko KV, Fedorova TV, Tyazhelova TV. Lignin-degrading peroxidases in white-rot fungus Trametes hirsuta 072. Absolute expression quantification of full multigene family. PLoS One. 2017 Mar;12(3): e0173813.

9. Huggett JF, Foy CA, Benes V, Emslie K, Garson JA, Haynes R, et al. Guidelines for Minimum Information for Publication of Quantitative Digital PCR Experiments. Clin Chem. 2013 Jun;59(6):892-902.

10. Zmienko A, Samelak-Czajka A, Goralski M, Sobieszczuk-Nowicka E, Kozlowski P, Figlerowicz M. Selection of reference genes for qPCR- and ddPCR-based analyses of gene expression in senescing barley leaves. PLoS One. 2015 Feb; 10: e0118226.

11. Dheda K, Huggett JF, Chang JS, Kim LU, Bustin SA, Johnson MA, Rook GAW, Zumla A. The implications of using an inappropriate reference gene for real-time reverse transcription PCR data normalization. Anal Biochem. 2005 Sep;344(1):141-143.

12. Abbal P, Pradal M, Muniz L, Sauvage FX, Chatelet P, Ueda T, Tesniere C: Molecular characterization and expression analysis of the Rab GTPase family in Vitis vinifera reveal the specific expression of a VvRabA protein. J Exp Bot. 2008 Jun, 59: 2403-2416.

13. Ruan W, Lai M. Actin, a reliable marker of internal control? Clin Chim Acta. 2007 Oct;385(1-2):1-5. 
14. Bas A, Forsberg G, Hammarstrom S, Hammarstrom ML. Utility of the housekeeping genes $18 \mathrm{~S}$ rRNA, beta-actin and glyceraldehyde- 3-phosphate-dehydrogenase for normalization in real-time quantitative reverse transcriptase-polymerase chain reaction analysis of gene expression in human $T$ lymphocytes. Scan J Immunol. 2004 Jun;59(6): 566-573.

15. Solanas M, Moral R, Esrich E. Unsuitability of using ribosomal RNA as loading control for Northern blot analyses related to the imbalance between messenger and ribosomal RNA content in rat mammary tumors. Anal Biochem. 2001 Jan;288(1):99-102.

16. Spanakis E. Problems related to the interpretation of autoradiographic data on gene expression using common constitutive transcripts as controls. Nucleic Acids Res. 1993 Aug;21(16): 3809-3819.

17. Suzuki T, Higgins PJ, Crawford DR. Control selection for RNA quantitation. Biotechniques. 2000 Aug;29(2):332-337.

18. Vandesompele, J, DePreter, K, Pattyn, F, Poppe B, Van Roy N, De Paepe A, et al. Accurate normalization of real-time quantitative RT-PCR data by geometric averaging of multiple internal control genes. Genome Biol. 2002 Jun;3:research0034.1.

19. Czechowsky T, Stitt M, Altmann T, Udvardi K, Scheible WR. Genome-wide identification and testing of superior reference genes for transcript normalization in Arabidopsis. Plant Physiol. 2005 Sep;139:517.

20. Foss DL, Baarsch MJ, Murtaugh MP. Regulation of hypoxanthine phosphoribosyltransferase, glyceraldehyde-3-phosphate dehydrogenase and beta-actin mRNA expression in porcine immune cells and tissues. Animal Biotech. 1998;9(1):67-78.

21. Warrington JA, Nair A, Mahadevappa M, Tsyganskaya M. Comparison of human adult and fetal expression and identification of 535 housekeeping/maintenance genes. Physiol Genom. 2000 Apr;2:143-147.

22. Cusick KD, Fitzgerald LA, Pirlo RK, Cockrell AL, Petersen ER, Biffinger JC. Selection and evaluation of reference genes for expression studies with quantitative PCR in the model fungus Neurospora crassa under different environmental conditions in continuous culture. PLoS One. 2014 Dec; 9(12):e112706.

23. Song $Y$, Wang $Y$, Guo $D$, Jing L. Selection of reference genes for quantitative real-time PCR normalization in the plant pathogen Puccinia helianthi Schw. BMC Plant Biol. 2019 Jan;19:20.

24. Lyu, Y, Wu, X, Ren, H, Zhou, F, Zhou, H, Zhang, X, et al. Selection of reliable reference genes for gene expression studies in Trichoderma afroharzianum LTR-2 under oxalic acid stress. J Microbiol Methods. 2017 Oct; 141:28-31.

25. Llanos A, François JM, Parrou J-L. Tracking the best reference genes for RT-qPCR data normalization in filamentous fungi. BMC Genomics. 2015 Feb;16:71.

26. Steiger MG, Mach RL, Mach-Aigner, AR. An accurate normalization strategy for RT-qPCR in Hypocrea jecorina (Trichoderma reesei). J Biotechnol. 2010 Jan;145(1):30-37.

27. Barron GL. New species and new records of Oidiodendron. Can J Bot. 1962 Apr; 40(4):589-607.

28. Hambleton S, Currah RS. Fungal endophytes from the roots of alpine and boreal Ericaceae. Can J Bot. 1997 Sep;75(9):1570-1581. 
29. Lumley TC, Gignac LD, Currah RS. Microfungus communities of white spruce and trembling aspen logs at different stages of decay in disturbed and undisturbed sites in the boreal mixedwood region of Alberta. Can J Bot. 2001 Jan;79(1):76-92.

30. Schild DE, Kennedy A, Staurt MR. Isolation of symbiont and associated fungi from ectomycorrhizas of sitka spruce. Eur J For Pathol. 1988 Feb;18(1):51-61.

31. Qian XM, El-Ashker A, Kottke I, Oberwinkler F. Studies of pathogenic and antagonistic microfungal populations and their potential interactions in the mycorrhizoplane of Norway spruce (Picea abies (L.) Karst.) and beech (Fagus sylvatica L.) on acidified and limed plots. Plant Soil. 1998 Feb;199:111-116.

32. Xiao G, Berch SM. Diversity and abundance of ericoid mycorrhizal fungi of Gaultheria shallon on forest clearcuts. Can J Bot. 1996 Mar;74(3):337-346.

33. Bergero R, Perotto S, Girlanda M, Vidano G, Luppi MA. Ericoid mycorrhizal fungi are common root associates of a Mediterranean ectomycorrhizal plant (Quercus ilex). Mol Ecol. 2000 Oct;9(10):16391649.

34. Couture M, Fortin JA, Dalpé Y. Oidiodendron-griseum robak - an endophyte of ericoid mycorrhiza in Vaccinium-spp. New Phytol. 1983 Nov;95(3):375-380.

35. Dalpé Y. Axenic synthesis of ericoid mycorrhiza in Vaccinium angustifolium Ait. by Oidiodendron species. New Phytol. 1986 Jun;103(2):391-396.

36. Stoyke G, Currah RS. Endophytic fungi from the mycorrhizae of alpine ericoid plants. Can J Bot. 1991 Feb;69(2):347-352.

37. Lacourt I, Girlanda M, Perotto S, Del Pero M, Zuccon D, Luppi AM. Nuclear ribosomal sequence analysis of Oidiodendron: towards a redefinition of ecologically relevant species. New Phytol. 2001 Mar;149(3):565-576

38. Perotto S, Martino E, Abbà S, Vallino M. 14 Genetic Diversity and Functional Aspects of Ericoid Mycorrhizal Fungi. In: Hock B. (eds) Fungal Associations. The Mycota (A Comprehensive Treatise on Fungi as Experimental Systems for Basic and Applied Research), vol 9. 2012. Springer, Berlin, Heidelberg.

39. Leake JR, Read, DJ. Experiments with ericoid mycorrhiza. Methods Microbiol. 1991;23:435-459.

40. Martino E, Morin E, Grelet GA, Kuo A, Kohler A, Daghino S, et al. Comparative genomics and transcriptomics depict ericoid mycorrhizal fungi as versatile saprotrophs and plant mutualists. New Phytol. 2018 Feb;217(3):1213-1229.

41. Rice AV, Currah RS. Physiological and morphological variation in Oidiodendron maius. Mycotaxon. 2001;79:383-396.

42. Tsuneda A, Thormann MN, Currah RS. Modes of cell-wall degradation of Sphagnum fuscum by Acremonium cf. curvulum and Oidiodendron maius. Can J Bot. 2001 Jan;79(1):93-100.

43. Daghino S, Martino E, Perotto S. Model system to unravel the molecular mechanisms of heavy metal tolerance in the ericoid mycorrhizal symbiosis. Mycorrhiza 2016 May;26(4):263-274. 
44. Kohler A, Kuo A, Nagy LG, Morin E, Barry KW, Buscot F, et al. Convergent losses of decay mechanisms and rapid turnover of symbiosis genes in mycorrhizal mutualists. Nat Genet. 2015 Feb;47(4):410415.

45. Casarrubia S, Martino E, Daghino S, Kohler A, Morin E, Khouja H et al. Modulation of Plant and Fungal Gene Expression Upon Cd Exposure and Symbiosis in Ericoid Mycorrhizal Vaccinium myrtillus. Front. Microbiol. 2020 Mar;11:341.

46. Vallino M, Drogo V, Abba' S, Perotto S. Gene expression of the ericoid mycorrhizal fungus Oidiodendron maius in the presence of high zinc concentrations. Mycorrhiza. 2005 Jul;15:333-344.

47. Vallino M, Martino E, Boella F, Murat C, Chiapello M, Perotto S. Cu,Zn superoxide dismutase and zinc stress in the metal-tolerant ericoid mycorrhizal fungus Oidiodendron maius Zn. FEMS Microbiol Lett. 2009 Apr;293(1):48-57.

48. Casarrubia S, Daghino S, Kohler A, Morin E, Khouja H, Daguerre Y et al. The Hydrophobin-Like OmSSP1 May Be an Effector in the Ericoid Mycorrhizal Symbiosis. Front. Plant Sci. 2018 May;9:546.

49. DiVietro L, Daghino S, Abba' S, Perotto S. Gene expression and role in cadmium tolerance of two PLAC8-containing proteins identified in the ericoid mycorrhizal fungus Oidiodendron maius. Fungal Biol 2014 Aug;118(8):695-703.

50. Deng LT, Wu YL, Li JC, OuYang KX, Ding MM, Zhang JJ, et al. Screening reliable reference genes for RT-qPCR analysis of gene expression in Moringa oleifera. PLoS One. 2016 Aug;11(8):e0159458.

51. Stanton KA, Edger PP, Puzey JR, Kinser T, Cheng P, Vernon DM, et al. A whole-transcriptome approach to evaluating reference genes for quantitative gene expression studies: a case study in mimulus. G3 (Bethesda). 2017 Apr; 7(4):1085-1095.

52. Bio-Rad. Droplet Digital ${ }^{\text {тм }}$ PCR Applications Guide. 2015 [cited 2020 Feb 20] 145 p. Available from: http://www.bio-rad.com/webroot/web/pdf/Isr/literature/Bulletin_6407.pdf

53. Zhang L, Jing X, Chen W, Bai J, Vasseur L, He W, et al. Selection of reference genes for expression analysis of plant-derived microRNAs in Plutella xylostella using qRT-PCR and ddPCR. PLoS One. 2019 Aug;14(8):e0220475.

54. Andersen CL, Jensen JL, Orntoft TF. Normalization of real-time quantitative reverse transcription-PCR data: a model-based variance estimation approach to identify genes suited for normalization, applied to bladder and colon cancer data sets. Cancer Res. 2004 Aug;64(15): 5245-5250.

55. Pfaffl MW, Tichopad A, Prgomet C, Neuvians TP. Determination of stable housekeeping genes, differentially regulated target genes and sample integrity: BestKeeper - Excel-based tool using pairwise correlations. Biotechnol Lett. 2004 Mar;26:509-515.

56. Rasmussen R. Quantification on the LightCycler instrument. In: Meuer S, Wittwer C, Nakagawara K, eds. Rapid Cycle Real-Time PCR: Methods and Applications. Heidelberg: Springer-Verlag Press; c2001. p. 21-34.

57. Livak KJ. ABI Prism 7700 Sequence Detection System User Bulletin \#2 Relative Quantification of Gene Expression. 2001 Oct [cited 2019 Sep 12]. Available from: http://tools.thermofisher.com/content/sfs/manuals/cms_040980.pdf 
58. Pearson V, Read DJ. The biology of mycorrhiza in the Ericaceae: I. The isolation of the endophyte and synthesis of mycorrhizas in aseptic cultures. New Phytol. 1973 Mar;72(2):371-379.

59. Martino E, Turnau K, Girlanda M, Bonfante P, Perotto S. Ericoid mycorrhizal fungi from heavy metal polluted soils: their identification and growth in the presence of zinc ions. Mycol Res. 2000 Mar; 104(3):338-344.

60. Perotto S, Peretto R, Faccio A, Schubert A, Varma A, Bonfante P. Ericoid mycorrhizal fungi: cellular and molecular bases of their interactions with the host plant. Can J Bot. 1995 Dec; 73(S1):557-568.

61. Manoli A, Sturaro A, Trevisan S, Quaggiotti S, Nonis A. Evaluation of candidate reference genes for qPCR in maize. J Plant Physiol. 2012 May;169(8):807-815.

62. Babicki, S, Arndt, D, Marcu, A, Liang, Y, Grant, JR, Maciejewski, A, et al. Heatmapper: web-enabled heat mapping for all. Nucleic Acids Res. 2016 Jul; 44(W1):W147-53.

\section{Figures}




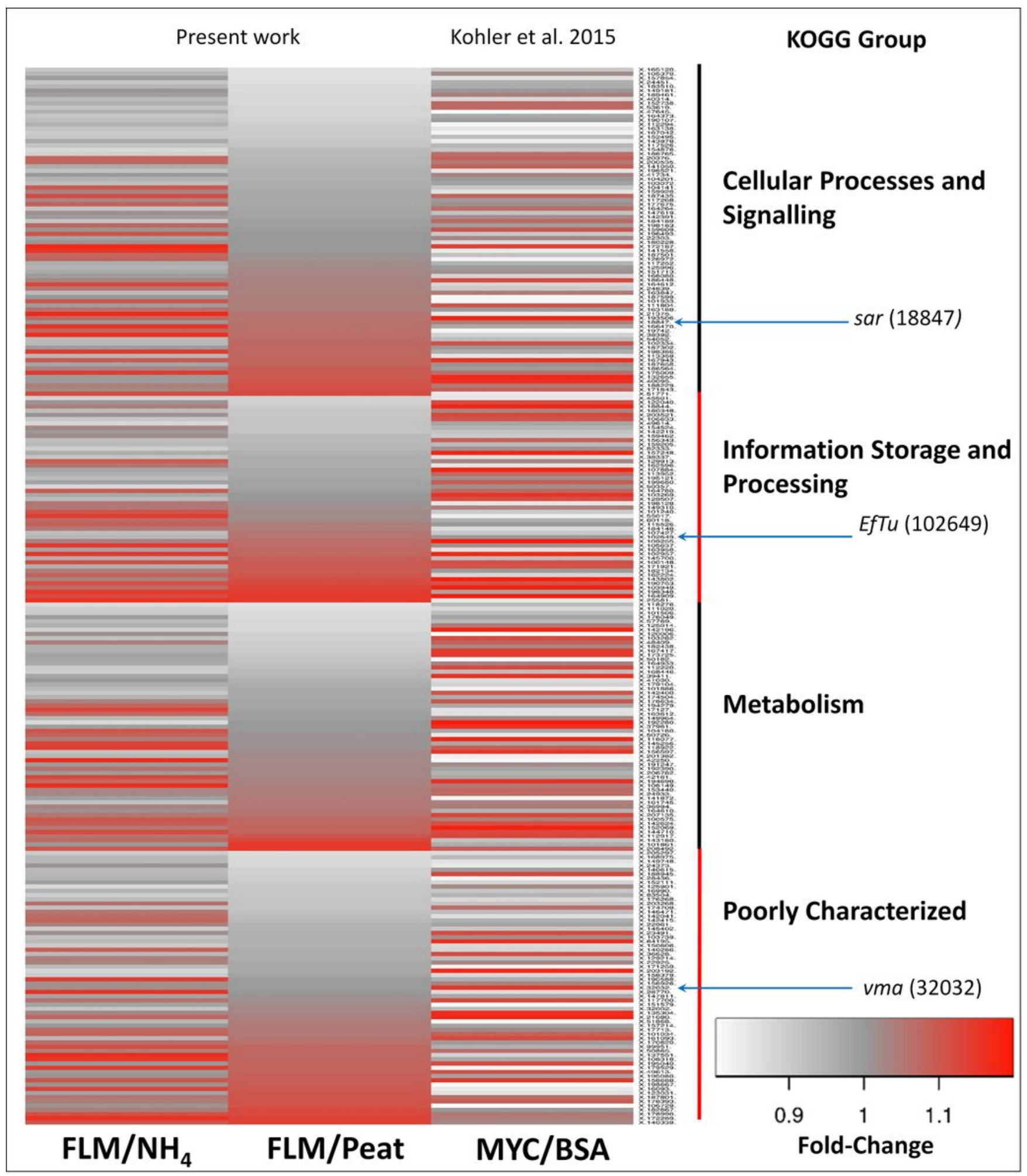

Figure 1

Gene expression analysis of 251 putative reference genes for Oidiodendron maius. Heat map illustrating RNA-Seq differential expression data and corresponding KOGG Group. White to red spectrum indicates increasing fold change (Reads Per Kilobase Million ratio) for each treatment compared with free-living mycelium (FLM) expression on Modified Melin Norkrans (MMN) without glucose and (NH4)2HPO4, supplemented with $0.1 \mathrm{~g} \mathrm{~L}-1$ bovine serum albumin (BSA) (FLM/BSA). Reference genes selected for 
validation are indicated by blue arrows; corresponding transcript IDs are in parentheses. Media used for each treatment are as follows - FLM/NH4: MMN (present work); FLM/Peat: MMN without glucose and (NH4)2HP04, poured over 10 g (dry weight) sterile commercial peat (present work); MYC/BSA: O. maius colonizing Vaccinium myrtillus root samples, grown on MMN without glucose and (NH4)2HPO4, supplemented with $0.1 \mathrm{~g} \mathrm{L-1}$ BSA (Kohler et al. 2015).
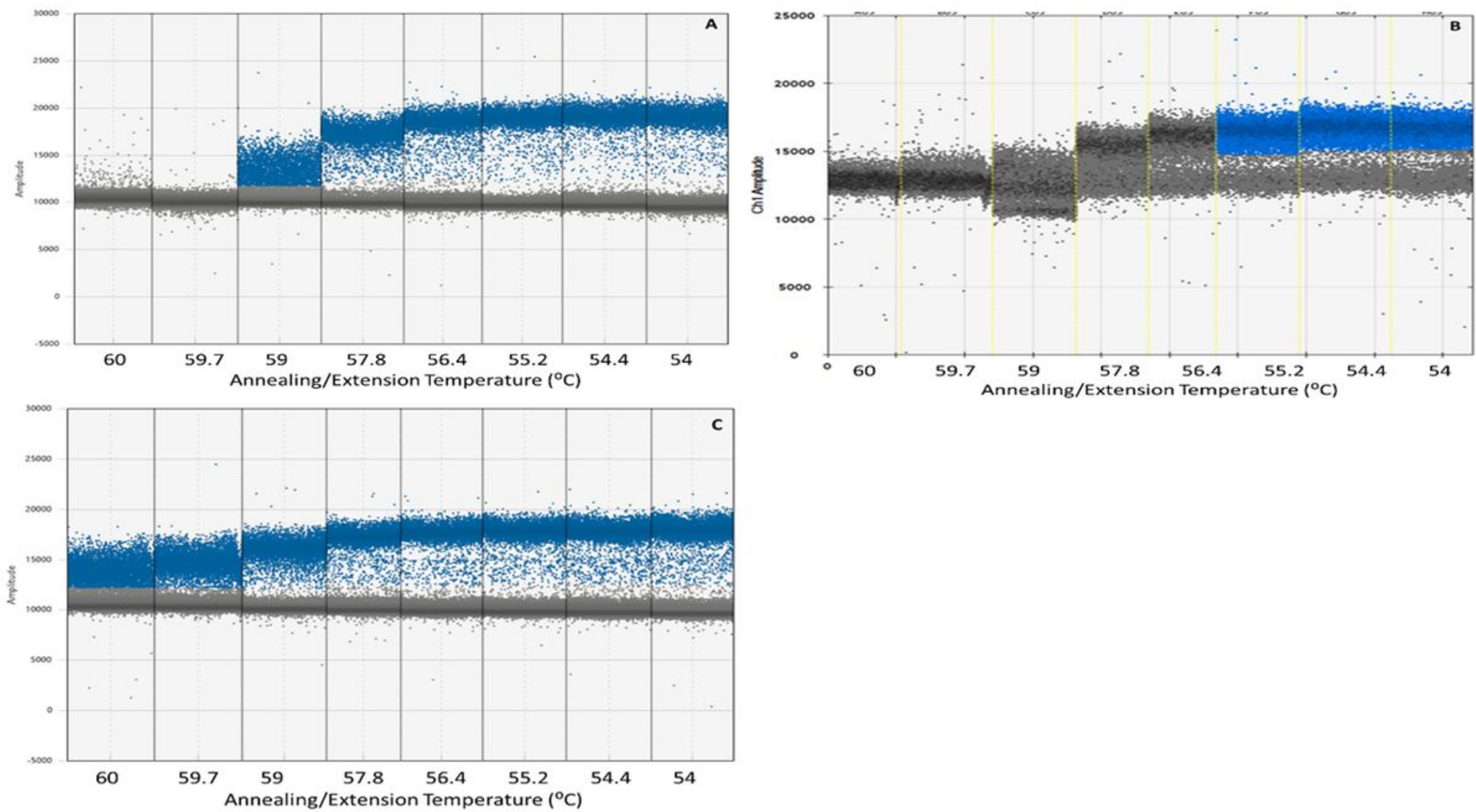

Figure 2

Optimization of primer annealing/extension temperature for ddPCR assays using temperature gradient. Fluorescence amplitude for eight annealing/extension temperatures ranging from $60^{\circ} \mathrm{C}$ to $54^{\circ} \mathrm{C}$ from left to right for ddPCR amplification of candidate reference genes (A) EFTu amplification using primer pair E22 (B) sar amplification using primer pair S12 (C) vma amplification using primer pair V35 

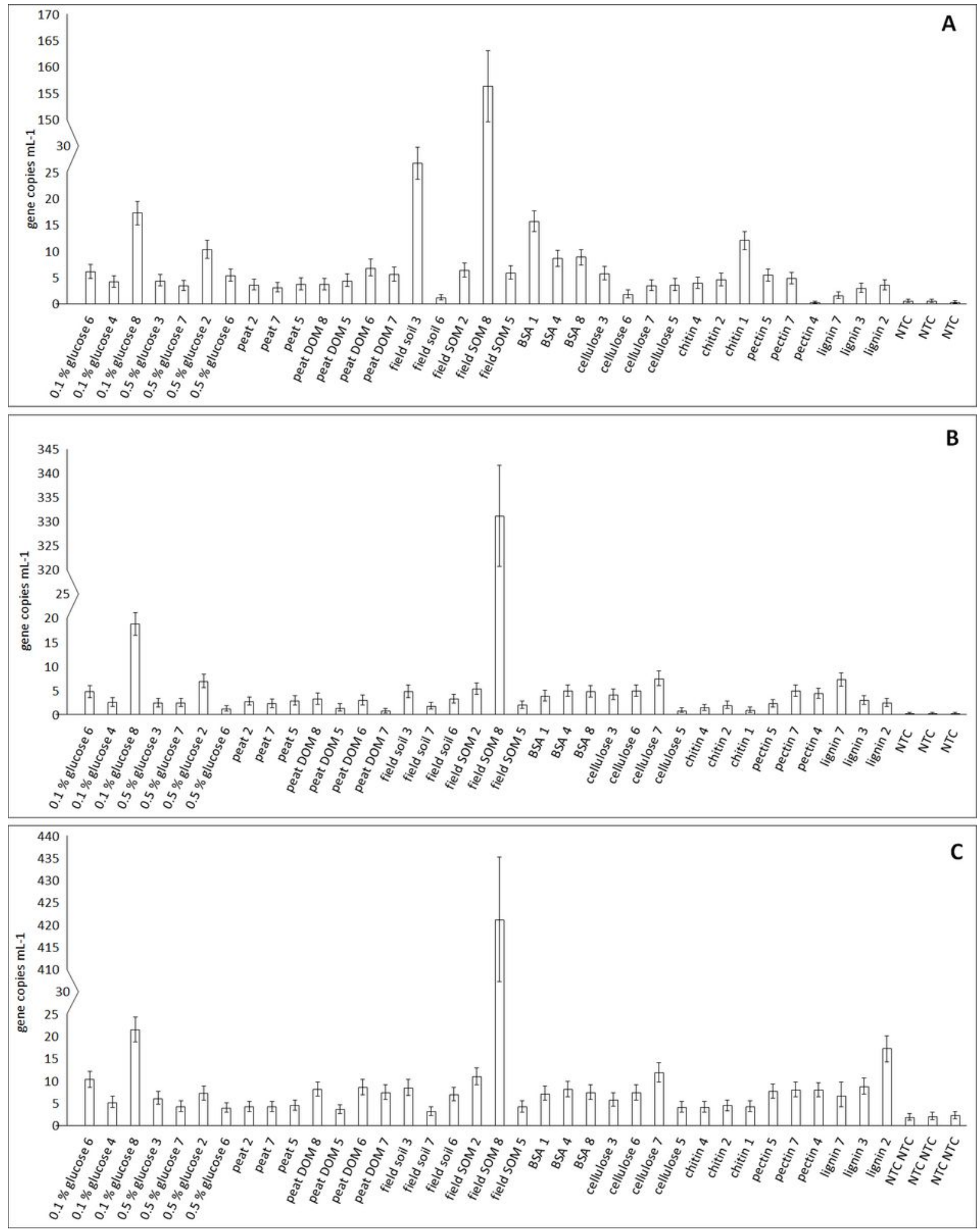

Figure 3

Reference gene concentration in 36 cDNA samples of Oidiodendron maius grown on a variety of carbon sources as determined by ddPCR. Error bars indicate the Poisson $95 \%$ confidence intervals for each concentration determination. (A) sar (B) EfTu (C) vma. Field soil sample 7 was omitted from plot A as an extreme outlier. (DOM: dissolved organic matter; SOM: soil organic matter; BSA: bovine serum albumin; NTC: no template control). 

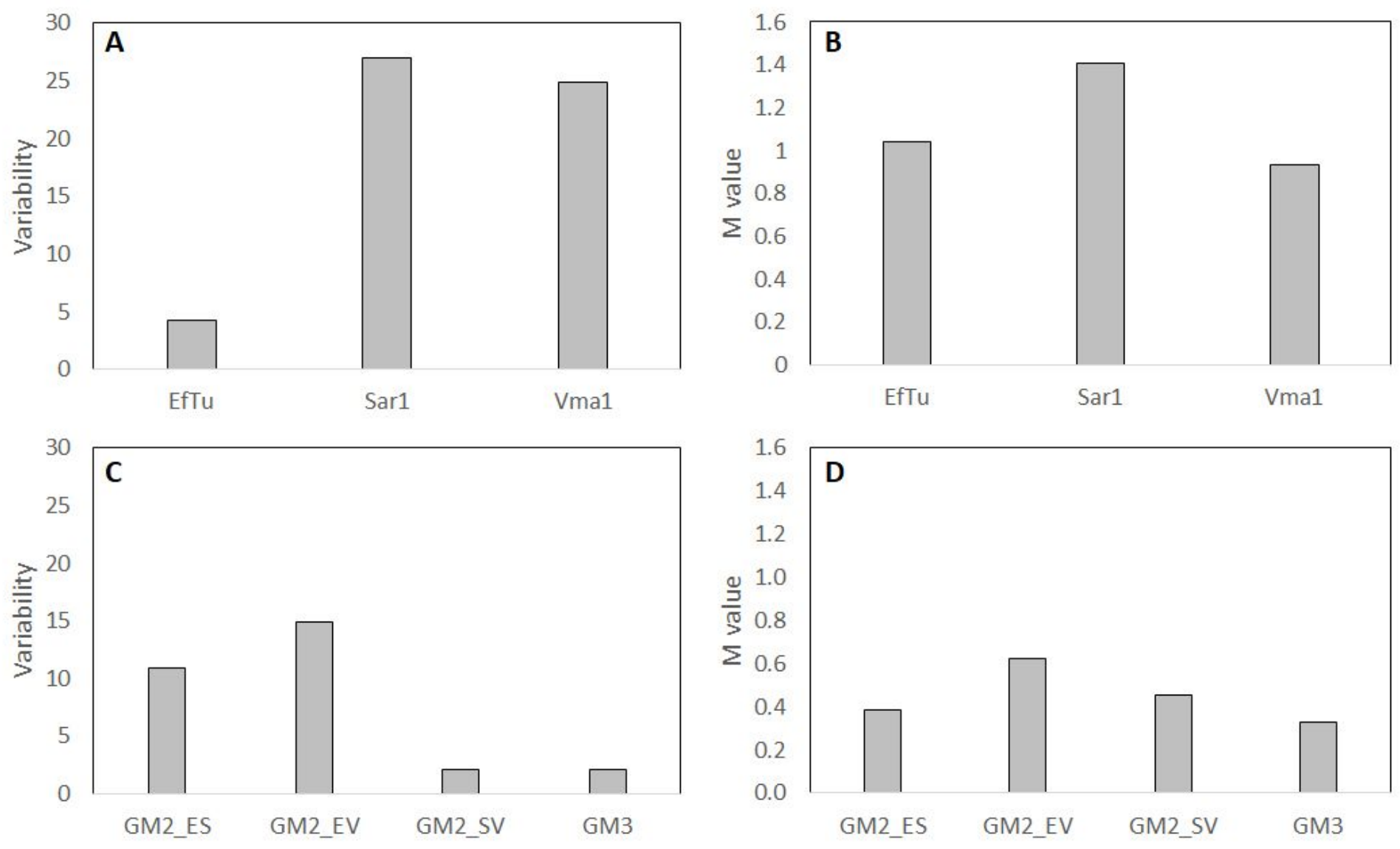

\section{Figure 4}

Identification of reference genes in Oidiodendron maius. Analysis of the stability of three different reference genes (EfTu, sar, vma) in 33 different samples (O. maius grown on 11 different carbon sources in biological triplicate), as calculated with NormFinder ( $A$ and $C$ ) and geNorm ( $B$ and $D$ ) algorithms. In addition to the analysis of the stability of the individual genes ( $A$ and $B$ ), these analyses were also performed on the geometric means of the expression value of the three genes (GM3) and the geometric means of each pair of reference genes (GM2ES: EfTu and sar; GM2EV: EfTu and vma; GM2SV: sar and vma) ( $C$ and D). The lower the variability (NormFinder) or the M-value (geNorm) for a certain gene, the more stable it is when evaluated by the corresponding algorithm.

\section{Supplementary Files}

This is a list of supplementary files associated with this preprint. Click to download.

- TableS1.xlsx 